Denis Boyle

University of Barcelona (Spain)

\title{
Historical Drawbacks of Limited Liability
}

\begin{abstract}
Limited liability is a human invention which has facilitated enormous economic growth around the world, particularly since the time of its general application in advanced countries during the nineteenth century. The individual legal identity of companies, coupled with the limited liability of their owners, has provided protection for investors from the risks associated with their investments. It has thus contributed to increase the sources of capital available to finance projects which might otherwise have been considered unviable. However, the legal protection offered to investors has negative consequences for other participants in economies. Speculation in stock markets often damages society. It is very important to study the drawbacks of limited liability and to suggest modifications to achieve a more stable, less volatile, economic growth in the world. Although this article goes to some lengths to recognise the work of authors who emphasise the positive historical economic contribution of limited liability, its main objective is to provoke a reflection around texts which point out the drawbacks and propose solutions.
\end{abstract}

Keywords: Commitment; Financial Speculation; Corporate Social Responsibility; Limited Liability; Multiple Liability.

Corresponding author. E-mail: denisboyle@yahoo.com

Received 27 November 2015 - Accepted 7 March 2016

This is an Open Access article distributed under the terms of the Creative Commons Attribution-Non-Commercial-No Derivatives License (http://creativecommons.org/licenses/by-nc-nd/4.0/), which permits non-comercial re-use and distribution, provided the original work is properly cited, and is not altered or transformed in any way. 


\section{Introduction}

This article will analyse a variety of academic texts which describe a series of drawbacks associated with the historical development of the limited liability model of business ownership and management. It is not intended to be an exhaustive survey of the issues involved, but rather an examination of some specific reflections and ideas proposed by some selected scholars. ${ }^{1}$

The ideas expressed will be compared with the extensive bibliography which defends contemporary financial institutions by studying the benefits they have provided throughout their history. To understand such theses, it will be important to examine the historical origins of limited liability and its development during recent centuries and to consider authors who express confidence in the future evolution of financial innovations.

We will then proceed to evaluate studies which suggest proposals to improve the operation of limited liability, some of which have been implemented at certain times during the contemporary period of history. They aim at correcting the imbalance created by protecting shareholders at the expense of other participants in economic activities.

\section{Drawbacks of the Limited Liability Business Model}

The limited liability company is a legal structure by which the capital ownership of a business is divided into shares. Shareholders do not respond personally for business debts: their liabilities are limited to the amount of their investment. The model has deep historical roots and is a fully consolidated in day-to-day commerce practically everywhere. However, during

\footnotetext{
${ }^{1}$ This article is based on a dissertation written in the summer of 2014 which formed part of the author's studies towards a Masters in Economic History in the Economic History Department of the University of Barcelona. The author wishes to acknowledge the advice provided by the Department, with special thanks to Yolanda Blasco Martel who supervised the original dissertation. Thanks are also due to the anonymous JESB reviewers for their appraisal and for their improvement suggestions.
} 
the history of its application the advantages and disadvantages of limited liability have been subject to vigorous debate in universities and political circles (Kindleberger 1988, Shiller 2004).

The Joint Stock Companies Act of 1856 generalised the creation of limited liability companies in England. In the parliamentary debate prior to voting Lord Curriehill ${ }^{2}$ predicted three major problems. Firstly, creditors would be subject to fraud either through their ignorance of the limited liability status of their debtors or through an excessive confidence in company accounts - often unreliable. Secondly, speculation would be increased because of the transfer of investor risk to company creditors and the consequent seduction of gullible investors expecting easy profits. Thirdly, for Lord Curriehill companies enjoying limited liability would benefit from a protection which would be unavailable to traditional businesses, thus creating unfair competition (Bryer 1997: 47).

The doubts which surrounded limited liability in England in 1856 were a reflection of the debate which had taken place forty-five years earlier in the United States prior to the approval of the 1811 New York Act which generalised the institution of the limited liability company in certain industrial sectors in North America. Robert J. Shiller (Shiller 2004: 271) refers to the work of the historian David Moss who documented an impressive number of arguments against the law that were debated by the American legislators (Moss 2004). Many political representatives considered that the protection offered to shareholders from the consequences of business losses would provide them with an incentive to carry out excessively risky operations. Under the new law shareholders would not have to pay all the losses incurred if

\footnotetext{
${ }^{2}$ Lord Curriehill (1794-1868): a prominent Scottish judge whose contribution to the debate is documented in parlamentary records.
} 
the results turned out to be negative, but would receive all the profits if the businesses were successful.

For many present-day authors, speculative investment in financial markets constitutes the principal drawback in relation to the legal structure of the limited company. Shareholders feel protected (due to the limitation of their liabilities) from the risks associated with the activities of the businesses in which they hold stock, and so they invest with a lower degree of caution than would be appropriate in other circumstances. In fact, speculation was worrying commentators as far back as the $18^{\text {th }}$ century, well before the general spread of limited liability companies, when they could only be created by special statute. Charles P. Kindleberger explains that many investors would sell their shares before paying for them in full and would show little interest in the progress of business projects (Kindleberger 1988: 267). Speculation forced the British government to severely restrict share operations and the Bubble Act of 1719-1720 practically prohibited the creation of new limited liability companies during a long period up to its repeal in 1825 (Galbraith 1991: 58-63).

Although a majority of economists expresses strong reservations about protectionist commercial policies (Krugman, Wells and Graddy 2011) few question protectionism as it applies to shareholders in limited companies. But the limited liability company is a legal creation that does not exist in any natural form, so it can and should be subject to review and modification in order to better satisfy the necessities of the human community. For this reason, the academic study of the corporate form is relevant for the future development of society (Hiller 2013: 287).

An important characteristic of limited liability is that the obligations of management to maximise shareholder profits are legal impositions. They do not stem from voluntary 
agreements, as might be the case with their principle obligations towards employees, customers or suppliers. Corporate laws impose on the directors a duty to direct their efforts towards the achievement of shareholder profit (Mayer 2013: 28-32). The consequences of these legal obligations can be very profound in relation to the personal ethics of the managers and their sense of social responsibility. A series of experiments has been carried out which demonstrates that the great majority of top executives in North American companies place profits before moral beliefs when confronted with opportunities to work for the general benefit of society. Even more interesting is that the same experiments have demonstrated quite different results in the case of partners in businesses which are not limited liability companies (Rose 2007: 323-330). The implication is that whatever effort that might be directed towards educating company managers in professional ethics is practically useless: their decisions will always be determined by their legal obligations to maximise profits.

There are many specific cases that can be studied in order to understand who might be the victims of this exclusive obligation to maximise benefits for shareholders whilst ignoring the interests of other business participants. Here, due to the need for brevity, we will consider just one example. The history of the British confectionery group Cadbury, and the struggle to control the company up to the time of its acquisition by Kraft in 2010, provides an illustration of the way corporations have been managed under the limited liability model (Bell 2013, Mayer 2013, Funding Universe 2014, Grace's Guide 2014). Throughout the $19^{\text {th }}$ century and a large part of the $20^{\text {th }}$ century the Cadbury family involved all the stakeholders $^{3}$ in the running of the business. The executives attended to the needs of the employees and demonstrated a

\footnotetext{
${ }^{3}$ Although the term stakeholder was not invented until the 1960's its anachronic application in this text is justified because it defines those participants in limited liability companies who are not shareholders. Such stakeholders can include employees, customers, suppliers, neighbours, regulators, governmental authorities, society in general and the environment.
} 
concern for the contribution of the business to the general well-being of society. However, important changes took place in the nineteen sixties when the company became an acquisition target for various shareholder groups interested in short-term gain. Cadbury was perceived to be in play in financial markets, subject to the attention of venture capitalists and public company takeover specialists ${ }^{4}$. It became an example of imbalances in the management of limited liability companies. The interests of one particular group (shareholders, beneficiaries of the legal protection which limited their liabilities) took priority over the rest, and the longterm financial performances of the businesses concerned were jeopardised.

In 2009 in the USA Kraft Foods Inc. launched a takeover bid for Cadbury plc. It met with fierce opposition from three groups: British public opinion because of the loss of a brand identified with the national culture; the main unions which feared a wave of redundancies as a result of the acquisition; and a significant number of politicians who were worried about the possible transfer of activities to other countries and a consequent avoidance of UK tax. Protests were also heard relating to the multi-million pound fees charged by the banks involved in the deal. Despite all these objections, however, Kraft Foods Inc. was able to complete the acquisition in February 2010 because it met with shareholder approval. The acquisition price was $£ 11,5 \mathrm{bn}$ (approximately $€ 14,5 \mathrm{bn}$ ), financed by borrowings of $£ 7,0 \mathrm{bn}$ (approximately $€ 9,0 \mathrm{bn}$ ). Paradoxically, the main lender turned out to be RBS, a bank controlled by the British government following the rescue of the banking sector during the financial crisis in 2008.

\footnotetext{
${ }^{4}$ Public company takeovers occur when a person (normally a limited company) makes an offer to buy the shares of a stock-market quoted company with the objective of achieving a significant participation in its capital and corresponding voting rights. In many cases takeovers constitute a threat to the employment of the directors of the target company who try to persuade shareholders to reject the offer. It should be noted that the term "public company" in the United Kingdom refers to the company's shares being held and traded by the general public and does not generally signify any kind of state ownership.
} 
Later in $2010 \mathrm{Kraft}$, despite earlier promises not to make lay-offs, began to announce the closure of English factories and the transfer of production to a series of countries with cheaper labour costs such as Poland. Furthermore, fiscal matters began to be dealt with in Switzerland as a means of saving tax, again in spite of promises to the contrary made during the acquisition process. The British government ordered an investigation. The managing director of Kraft, Irene Rosenfeld, was asked to appear on various occasions to answer questions from members of the parliamentary commission charged with preparing the corresponding report. However, Rosenfeld rejected all the requests and did not appear before the commission at any time. In 2011, following a declaration of disappointing results, the directors of Kraft decided to separate the confectionery business from the remainder of their interests. Since then Cadbury has formed part of a new company, Mondelez International Inc.

The importance of the Cadbury example is that it is not an isolated case in an unusual business sector. Many other companies in very traditional areas of business have experienced a similar evolution, a fact which would seem to contradict the widely accepted notion, supported by Frank H. Easterbrook and Daniel R. Fischel (Easterbrook and Fischel 1985: 9596), of takeovers being healthy mechanisms which always bring benefits.

\section{The Defence of Limited Liability Based on History}

There are a number of prestigious authors who consider that modern financial markets, based on limited liability, provide the basis of economic growth in the world. For Robert J. Shiller (Shiller 2004: 267-273 and 2012: 87-94) the essential aspects of limited liability became generally applicable to financial markets in the $19^{\text {th }}$ century. The 1811 New York Act not only allowed any business within permitted sectors (complying with certain prerequisites) to adopt company status, but also took the radically innovative step of stipulating that the liabilities of 
all their shareholders would be strictly limited. Before the passing of this Act, limited liability companies were practically always created as a result of privileges granted by government, and their general spread was impossible. Furthermore, before the changes creditors of companies in difficulties could impound the personal assets of shareholders - including the assets of small shareholders - until outstanding debts were paid.

The New York experiment was successful and with the passing of time all other states passed their limited liability Acts. California was the last to do so in 1931. The 1811 Act, which enabled New York to become a financial world leader, inspired corporate legislation in the United Kingdom, Germany, France and eventually almost all developed countries. Limited liability allowed investors to acquire large diversified portfolios of shares, previously unadvisable given that the failure of a single investment could result in financial ruin. It is interesting to observe that the inventors of limited liability legislation did not envisage diversification of portfolios, but one thing led to another and such diversification became a fundamental aspect of limited liability.

Shiller concludes that the history of humanity is a succession of financial inventions which have improved our lives (Shiller 2004: 281). Innovations which appear to be loaded with complexities and problems can turn into standard tools of risk management when professionals learn how to use them properly. So the invention of limited liability and its derivatives has and will have positive effects for everyone. Even after the financial crisis of 2008 Shiller expresses great confidence in the evolution of financial markets, considers the stock market to be a fantastic invention, distances the legal structure of companies from speculation stating that thanks to human weaknesses we are always subject to bubbles and 
bursts, and affirms that the enormous growth in the securitisation of mortgages in the United States arose .... because businesses tried to please regulators (Shiller 2012: 17, 88, 102). Max Gillman and Tim Eade (Gillman and Eade 1995: 20) explain that the evolution of the corporate form was related to changes in trading practices during the industrial revolution, characterised by a greater degree of specialisation. The expansion of trade created a need for organisational improvements to reduce transaction costs ${ }^{5}$. Just as manufactured products and workers were becoming more and more specialised, so the corporate structure needed to evolve. The incorporation of businesses and the limitation of the financial liabilities of shareholders appear to be products of this demand for specialisation in the corporate form.

In this respect the observations of the great industrial historian Alfred D. Chandler Jr. (Chandler 1990: 9-10) are also relevant. For this author the advantages of limited liability are evident. In the USA the spread of the railway and telegraph networks demanded the appearance of a new type of business. The massive investments necessary for their construction brought about a separation between ownership and management. Companies, now much larger, came to be managed by teams of professionals. Shareholders, now protected from possible ruin in the case of business failure, could afford to distance themselves from the day-to-day affairs of the businesses they owned.

Other authors emphasise the social benefits of the limited liability company. For R. A. Bryer (Bryer 1997: 38-39) commentators who favoured limited liability in the first half of the $19^{\text {th }}$ century had a social vision of capital which anticipated Marx's criticism of the individualistic thought proposed by Adam Smith. For these commentators unlimited liability implied a concentration of capital in the hands of an elite who controlled the management of their

\footnotetext{
${ }^{5}$ In economics a transaction cost is one which is incurred in order to carry out an economic interchange. Such a cost can be reduced by organizational improvements as well as through collaboration between businesses or between departments within the same business.
} 
businesses (they assumed all the risk and so felt compelled to exercise full operational control). Furthermore, for the capital to be social it was not only profits that had to be shared equally between investors but also losses - which was achieved by limiting such losses to the amount of capital invested.

David McBride (McBride 2011: 3) explains that the legal corporate structure had a number of advantages over other forms, the most important being the doctrine relating to limited liability. ${ }^{6}$ Since the construction of railway networks in the middle of the $19^{\text {th }}$ century large capital investments became essential for progress. The creation of common funds for numerous investors became an important means of raising capital, but investors were not disposed to place money in businesses which they did not control if they were to expose themselves to an unlimited liability for debts. In this respect the limitation of their liabilities was critical not only for the development of the corporation but also for the national economy in general. Other advantages of the corporate form included the use of modern management techniques which were developed during the late $19^{\text {th }}$ and the early $20^{\text {th }}$ centuries by professional managers who were not owners, as well as perpetual existence (considered below) and the ability to carry out mergers.

For Margaret Blair (Blair 2004: 3) one of the great advantages of incorporation ${ }^{7}$ for North American businesses in the $19^{\text {th }}$ century was related to the difficulties in the financing of complex projects which depended on a series of inputs during a long period of time and where outputs were not easily divisible in portions or parts attributable to the inputs. A business controlled by partners had the major disadvantage that any one of them could withdraw at any

\footnotetext{
${ }^{6}$ The word liability in English implies a legal obligation to make a payment. In some languages it has the same translation as responsibility although in English it does not have the moral connotation of such a term.

${ }^{7}$ Incorporation: the concession of an individual legal status to a business which thereby becomes a company or corporation. The liabilities associated with the business are passed to the company and no longer pertain to the shareholders as individuals.
} 
time, taking with him his part of the assets and so putting an end to the productive activity and dis-incentivising long-term projects. The invention of the joint stock company ${ }^{8}$ in the $17^{\text {th }}$ century provided an important tool to overcome this problem. Members could no longer withdraw their part of the assets but came to depend on the decisions of the directors regarding dividends. In this way companies were able to maintain the resources dedicated to their activities during a long-term horizon. Nevertheless, on the death of a shareholder it was possible for his heirs to withdraw the investment, a fact which demonstrated the still imperfect separation of ownership from management. This defect would take time to correct, with the relevant legislation not being implemented in some North American states until the beginning of the $20^{\text {th }}$ century. It decreed that, once committed, any capital invested in a corporation by its investors could not be withdrawn.

In summary, Blair is an enthusiast of the commitment of capital offered by the institution of limited liability companies. Their nature is perpetual and they are capable of contributing to the development of long-term projects independently of the time horizons of the owners of the shares at any one moment. The author notes the case of the American sewing-machine business $I$. M. Singer \& Co., originally owned by two partners: Isaac Merritt Singer and Edward Clark. The time came when Singer left the management in the hands of Clark and began to enjoy his wealth in the company of a succession of women with whom he had various children. Clark feared the break-up of the business on the possible death of his partner due to withdrawals by his many heirs. Finally, in August 1863 he managed to convince him by incorporating the business as the Singer Manufacturing Company and so separating the

\footnotetext{
${ }^{8}$ A Joint Stock Company is a business owned by shareholders. Its capital is divided into portions (or shares) such that ownership is proportional to the number of shares held. Today most joint stock companies are incorporated and the liability of shareholders is limited to the amount of their investment. However, historically these last two characteristics were not always found in joint stock companies.
} 
affairs of the owners from the management of the business and thus avoiding its possible closure on the death of his old partner (Blair 2004: 15-19).

Andrew A. Schwartz (Schwartz 2012: 765-830) also discusses the perpetual nature of the limited liability company. He attributes it the merit of ensuring a long-term future for the corporation which acts as an immortal investor. It allows for a sustainable growth in economies and implies a concern for the future which incentivises activities which are socially beneficial for the whole community. Immortal investors by definition expect less short-term profit than mortal ones, thereby creating a longer-lasting and more sustainable wealth. It is an extremely optimistic vision of the corporation. Schwartz considers that management short-termism can be solved by better education and by the use of techniques to promote a historical and long-lasting identity in the business (images, hymns, logos....). The same author recognises that many perpetual companies have human owners (and so can hardly be considered to be immortal in relation to their objectives), but points out that there are also a large number whose owners are other companies which do have a perpetual nature. Many of these questions relating to the impact of limited liability on business management are to be found in a practical case studied by Graeme Acheson and John D. Turner (Acheson and Turner 2006: 320-346). The basis of their work is data discovered in the archives of the Ulster Bank in Ireland which pertain to years both before and after the conversion of the bank to a limited liability company.

The two authors explain that during the major part of the $19^{\text {th }}$ century banks in Great Britain were dominated by unlimited liability companies. However, as a consequence of the failure of the City of Glasgow Bank in 1878 practically all banks decided to limit the liabilities of their shareholders. We therefore have a natural experiment by which it is possible to demonstrate 
the impact of the change in relation to ownership, control and management in the banking sector. Acheson and Turner demonstrate that limited liability for the banks in question strengthened their ability to access capital, increasing the number of shares and their dispersion. Shareholdings were no longer confined to the rich, and the number of shares in the hands of directors decreased - implying that the role of director came to correspond to professional managers rather than shareholders (Acheson and Turner 2006: 329-334).

Another author who explains the history of the limited liability company from a positive perspective with respect to its contribution to economic growth is Eduardo Andrades Rivas (Andrades Rivas 2011: 401-444). He investigated the very beginnings of the institution. His most interesting conclusion is that the shareholder company is not exclusive to capitalism but pertains to every advancing society. Quoting the Italian lawyer Lorenzo Mossa he sustains that it cannot be considered as the culminating achievement of capitalism and of liberalism which have favoured its existence and have coincided in time: It is the creation of every society and as such its destiny is to accompany society and, at certain times, to have its own destiny. The [socialist] revolution of this $\left[20^{\text {th }}\right]$ century, which planned its destruction, has ended up perfecting it instead of annihilating it (Mossa 1951).

For Andrades Rivas the origin of the limited liability company is to be found in the United Provinces of the Netherlands during the time of the war with Felipe II (king of Spain between 1556 and 1598). The conflict provoked the creation of a society or company which, benefitting from legal privilege and financed by hundreds of small investors, was able to confront the challenges of international trade. Later on, after its foundation in 1621, the Dutch East India Company would respond to this trading impulse. The liability of the investors would be limited to the price of the shares subscribed. 
The experience in France came later than in the Netherlands. The French East India Company was founded by the minister Colbert in 1664, and in 1717 the New Indies Company was set up. New instruments were created such as bearer shares, limited liability and the establishment of Boards of Shareholders. After the traumas of the French Revolution limited liability companies would again be authorised in 1796; and finally the Trade Regulations of 1807 would be applied to companies, thereby bringing them under State supervision.

A very interesting aspect of Andrades Rivas's work is that which relates to his observations surrounding the origins of the limited liability company in Spain. It appears that they were unrelated to events in the Netherlands and in France. This diversity of roots of the institution in different European countries backs up the author's hypothesis that sees the limited liability company as an invention common to all advancing societies, independent of capitalism.

So what has happened since those early days when the limited liability company offered such effective solutions in the development of commerce? For David McBride (McBride 2011: 18) it was created and was successful in a world which was simpler than it is today. The increase in the size and complexity of corporations and of financial markets has led to new problems with respect to the most efficient and fair organisation, combined with difficulties associated with the maintenance of the confidence necessary for its effective operation in society and in markets, and with the facilitation of a healthy flow of information and communication between interested parties. It may be that modern challenges demand an experimentation with new organisational structures in order to determine, by a process of trial and error, which are the ones that best overcome the difficulties. 
In his conclusions McBride, rather than question the limited liability model, considers it to be an early step in economic evolution. Corporate law should therefore be flexible in order to promote new social technologies and adapt itself to change. For example, the law should be sufficiently elastic to be able to tackle the perennial conflicts that exist between the interests of shareholders and other participants in business activities such as suppliers, customers and workers (McBride 2011: 12-14).

However, what for McBride are gentle movements in an evolutionary process, for others respond to moments of crisis. An editorial about financial crises published in the weekly magazine The Economist (12-18 April 2014: 47) states that institutions [and instruments] that enhance people's economic lives such as central banks, deposit insurance and stock exchanges, are not the products of careful design in calm times, but are cobbled together at the bottom of financial cliffs. Often what starts out as a post-crisis sticking plaster becomes a permanent feature of the system. In the same way for Nicholas Kyriazis and Theodore Metaxas (Kyriazis and Metaxas 2011: 364) decisions which change history are taken in response to shocks and lead to new paths. They provoke the development of new institutions and organisations which demand significant investments linked to benefits for society in general. During the periods that follow, these investments become sunk costs which impede a return to the previous path. The authors explain that the shock which caused the invention of the Joint Stock Company in the United Provinces of the Netherlands in the $17^{\text {th }}$ century was the rebellion against Spanish domination. The creation of the Dutch East Indian Company permitted the capture of a lucrative spice trade from the enemies. In this way they conclude that the shock of the rebellion broke the evolutionary economic process. The implication is that it is very difficult to correct harmful deviations in the direction of economic evolution without the emergence of 
new shocks. From this perspective McBride's notion of the limited liability company forming part of a steady evolutionary process is not so clear.

So how can the limited liability model be improved without waiting for some kind of major crisis or shock to forcibly change our economic systems? The next section looks at some ideas.

\section{Possible Solutions to Improve the Limited Liability Model}

\section{Multiple liability}

To look for a first possible solution to improve the limited liability model we can refer to studies carried out by Richard S. Grossman (Grossman 2001: 143-159 and 2007: 59-80) into the concept of multiple liability as it existed between the end of the Civil War in 1865 and the nineteen thirties' Great Depression in the United States banking sector. The idea was to make shareholders liable up to a limit of a multiple (normally two, hence the denomination double liability) of the amount of their investment. Expressed another way, under double liability shareholders in failed banks could lose, in addition to the initial acquisition value of their shares, a further amount equal to the nominal value. Grossman concludes that double liability reduced the risks taken on by banks, although it did not necessarily guarantee stability in times of crisis.

The identification of reductions in the risks taken on by businesses is important for this article because it implies a greater concern on the part of shareholders about the consequences of business activities. By sharing losses with other business participants, they have an incentive to demand a style of management more in line with the interests of everyone involved. Furthermore, double or multiple liability is interesting because it offers an alternative to more 
regulations in the banking sector. It foments self-regulation imposed by shareholders and acts as a market-driven mechanism to reduce banking risk.

The practice of multiple liability terminated in the nineteen thirties, principally for three reasons. Firstly, the financial ruin of many shareholders who had had no influence in the management of failed banks generated political pressure to change the law. Secondly, the wave of banking failures in the nineteen thirties was believed to imply that the law had not fulfilled its objectives. Thirdly and perhaps most importantly, the imposition of federal insurance for deposits was held to indicate that multiple liability was no longer relevant. Early evaluations by contemporary authors concluded that the decision of the majority of states to abandon multiple liability in the nineteen thirties constituted irrefutable proof of its inefficiency (Marquis and Smith 1937: 502). However, more recent quantitative studies, like Grossman's, have thrown a more favourable light on the experience.

In order to ascertain whether multiple liability affected risk-taking in banks Grossman examined their balance sheets and looked at data surrounding bank failures as a means of evaluating management policy. He recognised that the use of such data had its limitations as a way of measuring operational risk but other options were just too complicated.

Grossman concludes that it is possible that shareholder liability laws did play a role in the assumption of risk by managers, and that multiple liability did reduce banking risk in the late $19^{\text {th }}$ century and early $20^{\text {th }}$ century. The effects could be seen in the rate of failures, capital / asset ratios, and liquidity rates of banks in states where multiple liability was adopted. It is true that these state banks were unable to avoid the effects of the crisis during the nineteen thirties, but such effects have generally been evaluated using data on liquidations and Grossman suggests that in many cases prudent bankers would be the first to liquidate their 
operations - in order to prevent future losses. Jonathan Macey and Geoffrey Miller (Macey and Miller 1992: 53-54) have no doubts about this. They consider that the early closure of banks facing difficulties - before getting to the stage where liabilities exceeded assets ensured that all creditors were paid. Even in the most difficult period between 1930 and 1934 depositors' losses in national banks (with multiple liability) amounted to no more than seventy-seven cents per thousand dollars. For these two authors history has demonstrated that in the USA a mistake was made when multiple liability was abandoned in favour of a deposit insurance scheme administered by the government.

\section{Corporate Social Responsibility}

The idea of Corporate Social Responsibility (CSR) represents a continual commitment on the part of an organisation to behave ethically and contribute to economic development whilst endeavouring to improve the quality of life of its employees (and their families), local communities and society in general (Lindgreen and Swaen 2010: 3, Watts and Holme 1999). It could be said that its application constitutes a recognition of the need to compensate imbalances created by the legal form of limited liability which obliges business managers to work exclusively for the benefit of shareholders.

For Richard Marens (Marens 2012: 64-76) the earliest ideas relating to CSR arose in the United States in the nineteen twenties as a consequence of the independence achieved by corporate executives with respect to worker demands. Once the development of union organisations had been stunted (with the help of government), during the second and third decades of the $20^{\text {th }}$ century an important segment of Corporate America tried to establish itself as a group of responsible employers and so consolidate the peace by nurturing satisfied and productive workforces and an understanding public. Many executives considered 
themselves to be intermediaries whose objective was to balance the interests of the different classes of person associated with their businesses (Marens 2012: 75). Although the term stakeholder wasn't invented until the nineteen sixties, it seems clear that the concept was already being developed. In 1917 Henry Ford explained that the objectives of his company were for everyone to be able to contribute, to create employment, to manufacture a car which people wanted.... and by the way to make a profit. He introduced the notion of business as a service to society (Lee 2008: 54).

During the Great Depression and the interventionist policies of the New Deal, corporations paid less attention to their social obligations. However, once the Second World War was over, CSR began to grow. A book published in 1953 by Howard Bowen, Social Responsibilities of the Businessman (Bowen 1953), described the obligations of businesses with respect to the social consequences of their activities. It was a work which provided the necessary intellectual backing to reflect on the rapid social change which would take place in the following decades. During the nineteen fifties and sixties numerous new laws were enacted to regulate business and to protect employees and consumers. Furthermore, the birth of a large number of consumer protest movements led to declarations by companies about CSR and to hundreds of books and articles analysing the issue (Lee 2008: 56-58). Nevertheless, publications critical of CSR also began to appear. In 1962 Milton Friedman (Friedman 1962) argued that the only social responsibility of a corporation was to make money for its shareholders and considered CSR to be a subversive doctrine. Ned Dobos (Dobos 2011: 273) explains that for libertarians being a shareholder was not a manner of avoiding natural positive duties (benefitting from the participation in a company without assuming the associated responsibilities), because such duties did not exist. 
In the nineteen seventies new justifications of CSR appeared based on the benefits it could provide for shareholders. In 1970 H. C. Wallich and J. J. McGowan (Wallich and McGowan 1970) argued that the long-term interests of shareholders were coherent with a correct social attitude on the part of business. Their ideas were further developed in the nineteen eighties following A. B. Carroll's model of Social Corporate Yield (Carroll 1979) which integrated the economic and social objectives of business. The model was made practicable in the nineteen nineties following the establishment of concrete definitions for the various stakeholder groups involved in business activity (Lee 2008).

Despite all this, the issue continues to be hotly debated. Antonio Tencati y Laszlo Zsolnai (Tencati and Zsolnai 2009: 369) comment that CSR is no more than another element of the traditional company model. It does not create neither any kind of moral commitment nor any profound change in the way business is analysed. It is taken to be one more tool available to improve corporate economic performance. They refer to M. E. Porter and M. R. Kramer (Porter and Kramer 2006) for whom the corporate offer can be improved by a socially responsible positioning. Tencati and Zsolnai are not attracted by such a proposition. Their perception is that CSR has been turned into an instrument exclusively focussed on maximising profits for shareholders and as such is prejudicial to the environment, today's society, future generations and finally the businesses themselves. They believe that the strength and sustainability of a company rests on its ability to adapt to its environmental, social and cultural context. It is only through the creation of values by and for the benefit of all stakeholders that companies can involve them and achieve a profound support based around their commitment. 


\section{Means to Create Greater Investor Commitment}

As has been observed in the case of Cadbury, one of the major drawbacks of the limited liability company is the short-termism of shareholders who tend to speculate rather than invest. Directors of quoted companies are constrained in their management by the presence in the shareholders' register of new members who are looking for quick profits. These members provoke instability because they seek a rapid revaluation of their shares arising from the volatility which derives from rumours about a possible takeover, a higher takeover offer, a sudden change in sales or production strategy, the substitution of existing directors for new more aggressive managers, or even the cancellation of long-term investment projects.

The ownership of quoted companies is often decided by short-term shareholders. In the case of Cadbury Roger Carr, Chairman of the Board, explained in a speech in Oxford University on $9^{\text {th }}$ February 2010 that in the end it was the change in the shareholders' register that lost the takeover battle against Kraft - the owners of the shares became progressively dominated by financial investors, interested only in quarterly results, in place of long-term administrators. In the final moments there were insufficient shareholders prepared to consider the long-term future of the company and sacrifice an immediate gain in favour of long-term prosperity...individuals who had controlled their shares during a few days or weeks decided the fate of a company that had been built up during the best part of 200 years (Mayer 2013: 92).

For Colin Mayer a corporation is characterised by a diversity of commitments - to shareholders and to other stakeholders. However, shareholders are able to practice speculative dealing which forces directors to offer them an immediate reward. In many cases they achieve 
such rewards by investing in hedge funds ${ }^{9}$ which buy shares in companies with the idea of control or acquisition, in both cases obliging directors to increase dividend payments. In this way, shareholders have an advantage over other participants in the business's activities. They can take cash out of the company because they have voting rights over its future. By this means an investment fund can buy shares in a company subject to a takeover bid. By doing so it assumes no responsibility for the company's operations nor any commitment to other participants. It can use the shares to vote in favour of the takeover and so achieve an immediate profit - a process which thus provides a means of diverting corporate profits in favour of one of the participants, the shareholder, at the expense of the others (Mayer 2013: 185-186)

One proposal to avoid such a diversion of profits would be to grant more independence to directors. However, this solution would create agency problems relating to the directors seeking personal gains in detriment to the corporation. Other more interesting proposals focus on differentiating investors in accordance with their degree of commitment.

Currently any assessment of the commitment of shareholders is very difficult because there is no way for them to indicate their intentions regarding the time they expect to maintain ownership of their holdings. Hence those who wish to sell after a few days have the same voting rights on company decisions as those who wish to retain their holdings for a number of years. The first group bear the consequences of their voting decision during an insignificant period, and the second group during an extended period. But both groups exercise the same influence at the time of taking a decision that can affect the results of the company for many

\footnotetext{
${ }^{9}$ Hedge funds are investment funds originally conceived to protect investors by providing a means of making small investments, the results of which were expected to inversely reflect the market (hence insuring an investment portfolio in the face of market movements). In practice they are often used as instruments of financial speculation.
} 
years. It is interesting to note in this context that, according to the German ex-banker Rainer Voss, two decades ago a share would be held by its owner for an average of a few days, whilst today the average length of ownership is twenty-two seconds (Voss 2013).

Mayer proposes that shareholders should register the time period during which they intend to retain their shares and that they should receive voting rights corresponding to the time remaining up to disposal. Thus a share with ten years to go before maturity should have ten times the vote of one with only a year up to maturity. Those shareholders who do not wish to commit themselves to keeping their shares could maintain them outside the register and forego voting rights. In this way the company would be able to access short-term capital in the financial markets which would thereby continue to exercise a very important role in the fixing of share prices and the flow of information, but would be controlled by committed shareholders (Mayer 2013: 206-214).

This proposal of a register would concede voting rights in proportion to the future commitment of shareholders and would restrict decisions concerning takeovers to shareholders committed to the future prosperity of the company in the long term.

\section{Conclusion}

Since its beginnings the institution of the limited liability company has been subject to debate. The limitation of shareholders' responsibilities transfers business risks to other participants in the company's activities such as suppliers, customers and workers.

Limited liability's main drawback relates to speculation in financial markets. The corporate form separates ownership from management, a fact which promotes diversification in investment portfolios by individuals who are not involved in the activities of the business nor 
wish to be informed about those activities. The limitation applied to their liabilities is key to their sense of security in the face of investment risk.

In this way acquiring shares in companies has been turned into a purely financial operation. Investors are motivated by short-term profit objectives and managers are ever more obliged to work towards goals which have little or nothing to do with the prosperity of the company in the long-term.

The study of the history of limited liability and its impact on economic development is very important in order to evaluate not just the drawbacks but also the positive aspects of its invention. It has made rapid economic growth possible, facilitating the provision of capital for projects which would otherwise been delayed or considered to be unviable. Many authors not only praise these aspects of limited liability but consider that they form part of an evolutionary process, always positive, which will lead to ever more sophisticated forms of investment and which will bring greater economic success.

Nevertheless, the objective of this article has been to point out failures in the corporation. An increasing number of texts support the need to find ways of achieving growth which seek the commitment of all the members of a company in equal measure. They invite a reflection on the drawbacks of a legal form which stresses the relationship between two participants (shareholders and managers) in detriment to all the others.

The historical application of the concepts of multiple liability and Corporate Social Responsibility demonstrate the recognition by society of difficulties associated with the limited liability model; and recent proposals concerning the need to compensate the economic privileges that limited liability concedes to shareholders, by means of enforcing greater 
commitment and voting rights proportional to that commitment, are worthy of serious reflection.

\section{References}

Acheson, Graeme, and John D. Turner. 2006. "The Impact of Limited Liability on Ownership and Control: Irish Banking, 1877-1914.” The Economic History Review, New Series 59(2): 320-346. Andrades, R. Eduardo. 2011. "La Sociedad Anónima en la Tradición Jurídica Hispano-Indiana." Revista de Estudios Histórico-Jurídicos (Sección Historia del Derecho Hispano-Indiano), XXIII: 401-444.

Bell, Gareth. 2013. "Restoring trust in the corporation: an interview with Colin Mayer, Peter Moores Professor of Management Studies at Said Business School and author of "Firm Commitment."” Strategic Direction 29(6): 35-39.

Blair, Margaret. 2004. "Reforming Corporate Governance: What History Can Teach Us." Berkeley Business Law Journal 1: 1-44.

Bowen, H. 1953. Social Responsibilities of the Businessman. New York: Harper.

Bryer, R. A. 1997. "The Mercantile Laws Commission of 1854 and the Political Economy of Limited Liability." The Economic History Review, New Series 50(1): 37-56.

Carroll, A.B. 1979. "A three-dimensional conceptual model of corporate performance." Academy of Management Review 4: 497-505.

Chandler, Alfred D. Jr. 1996 (1990). Escala y Diversificación. La Dinámica del Capitalismo Industrial. Zaragoza: Prensas Universitarias de Zaragoza.

Dobos, Ned. 2011. "Non-Libertarianism and Shareholder Theory: A Reply to Schaefer." Journal of Business Ethics 98: 273-279.

Easterbrook, Frank H., and Daniel R. Fischel. 1985. "Limited Liability and the Corporation." The University of Chicago Law Review 52: 1.

Friedman, M. 1962. Capitalism and Freedom. Chicago: Chicago University Press.

Funding Universe. 2014. Source for the history of companies:

www.fundinguniverse.com/company-histories/cadbury-schweppes-plc-history/

Galbraith, John K. 1991. Breve Historia de la Euforia Financiera. Barcelona: Ariel Editorial.

Gillman, Max, and Tim Eade. 1995. "The Development of the Corporation in England, with Emphasis on Limited Liability.” International Journal of Social Economics 22(4): 20-32.

Grace's Guide 2014. "Source for the history of UK industry and companies." http://www.gracesguide.co.uk 
Grossman, Richard S. 2001. "Double Liability and Bank Risk Taking." Journal of Money, Credit and Banking 33(2): 43-159.

Grossman, Richard S. 2007. "Fear and greed: the evolution of double liability in American banking, 1865-1930." Explorations in Economic History 44: 59-80.

Hiller, Janine S. 2013. "The Benefit Corporation and Corporate Social Responsibility." Journal of Business Ethics 118: 287-301.

Kindleberger, Charles P. 1988. Historia Financiera de Europa. España: Crítica.

Krugman, P. Wells, R., and K. Graddy. 2011. Essentials of Economics. New York: Worth Publishers.

Kyriazis, Nicholas and Theodore Metaxas. 2011 "Path Dependence, Change and the Emergence of the First Joint-Stock Companies.” Business History 538(3): 363-374.

Lee, Min-Dong Paul. 2008. "A Review of the Theories of Social Responsibility: Its Evolutionary Path and the Road Ahead." International Journal of Management Reviews 10(1): 53-73.

Lindgreen, Adam and Swaen, Valérie. 2010. "Corporate Social Responsibility.” International Journal of Management Reviews 12(1): 1-7.

Macey, Jonathan R., and Geoffrey P. Miller. 1992 "Double Liability of Bank Shareholders: History and Implications." Wake Forest Law Review Rev. 31.

Marens, Richard. 2012. "Generous in Victory? American Managerial Autonomy, Labour Relations and the Invention of Corporate Social Responsibility." Socio-Economic Review 10: 59-84.

Marquis, Ralph W., and Frank P. Smith. 1937. "Double Liability for Bank Stock.” The American Economic Review 27(3): 490-502.

Mayer, Colin. 2013. Firm Commitment. Oxford: Oxford University Press.

McBride, David. 2011. "General Corporation Laws: History and Economics." Law and Contemporary Problems 74: 1-18.

Moss, David. 2004. When All Else Fails: Government as the Ultimate Risk Manager. Cambridge, Massachusetts: Harvard University Press.

Mossa, Lorenzo. 1951. Trattato del nuovo diritto comerciale. IV:5. Italy: Padova.

Porter, M.E. and Kramer, M.R. 2006. "Strategy and Society: The Link Between Competitive Advantage and Corporate Social Responsibility." Harvard Business Review 84(12): 78-92.

Rose, Jacob. 2007. "Corporate Directors and Social Responsibility. Ethics versus Shareholder Value." Journal of Business Ethics 73: 319-331.

Schwartz, Andrew. 2012. “The Perpetual Corporation.” George Washington Law Review, 80.

Shiller, Robert J. 2004. "Las Lecciones de los Principales Inventos Financieros.” In El Nuevo Orden Financiero. El Riesgo en el Siglo XXI, edited by Robert J. Shiller, 267-281. España: Ed. Turner. Shiller, Robert J. 2012. Las finanzas en una Sociedad Justa. Barcelona: Deusto. 
Tencati, Antonio, and Laszlo Zsolnai. 2009. "The Collaborative Enterprise.” Journal of Business Ethics 85: 367-376.

Voss, Rainer. 2013. Master of the Universe. Documentary film produced in Germany by Katrin Klöntrup.

Wallich, H.C, and J.J. McGowan. 1970. "Stockholder interest and the corporation's role in social policy." In A New Rationale for Corporate Social Policy edited by W. J. Baumol. New York: Committee for Economic Development.

Watts, P., and Holme, R. 1999. Meeting Change Expectations. Corporate Social Responsibility. Geneva: WBCSD.

This is an Open Access article distributed under the terms of the Creative Commons Attribution-Non-Commercial-No Derivatives License (http://creativecommons.org/licenses/by-nc-nd/4.0/), which permits non-comercial re-use and distribution, provided the original work is properly cited, and is not altered or transformed in any way. 